\title{
基于协同育人的高职“课程思政”工作模式研究 以机电一体化专业为例
}

\author{
彭 清 张 慧 \\ 宁波城市职业技术学院 \\ DOI:10.32629/mef.v1i1.10
}

[摘 要] 高职普遍缺少推动“协同育人”的有效机制, 各教学单位、各学科之间缺乏协同与合作。在传统教学中, 教师“重 专业轻文化”, 学生文化课程基础较差、对思政教育漠不关心, 自我意识和叛逆心理突出, 因此, 高职学生思想政治教育很 少形成优势互补的合力工作局面。本文拟以机电一体化专业为例, 从梳理高职院校“棵程思政”协同育人的现状, 分析其 成因为契入点, 尝试探索基于协同育人的高职院校“课程思政”的工作模式, 以期改善当前高职院校大学生思想政治教育 的工作局面。

[关键词] 课程思政;机电一体化专业;协同育人

习总书记在全国高校思政会议上提出“要用好课堂教 学这个主渠道, 思想政治理论课要坚持在改进中加强, 提 升思想政治教育亲和力和针对性, 满足学生成长发展需 求和期待,其他各门课都要守好一段渠、种好责任田,使各 类课程与思想政治理论课同向同行,形成协同效应。”总 书记的这一论断指出高校所有课程都应该发挥思政教育 的重要作用。“课程思政, 实质是一种课程观, 既不是增开 一门课, 也不是增设一项活动, 而是将高校思想政治教育 融人课程教学和改革的各环节、各方面, 实现立德树人润 物无声的效果。”高职机电一体化专业“课程思政”协同育 人就是为了在所有课程中挖掘、融人思政要素, 在培养专 业人才的同时, 让学生接受素潜移默化的人文熏陶, 实现 专业技术精湛、职业素养良好的“金牌员工”人才培养目标。

\section{一、机电一体化专业“课程思政”协同育人的现状与成因}

长期以来, 就专业教学而言, 校本级缺少推动“协同 育人”的有效机制, 承担思政教育具体任务的单位 (部门) 本身缺乏“协同育人”理念而各司其职, 学科之间缺乏协同 与合作, 重专业轻文化的传统教学观念, 未形成优势互补 的合力工作局面; 就专业学习而言, 高职学生往往一般具 有文化课程基础较差、对思政教育漠不关心, 自我意识和 叛逆心理突出等特质, 从而导致了学生职业习惯不良、职 业道德意识淡薄、社会责任感不强、岗位适应性较弱, 价值 观念偏颇等问题。

以机电一体化专业为例, 《人才培养方案》中没有从 战略高度构建思想政治课程、职业素养课程、专业教育课 程三位一体的课程思政教育体系; 专业课程中的思政教 育元素未被充分挖掘; 专业教学与思政教育各司其职; 受 传统观念影响, 师生普遍重专业轻文化, 学生对人文素养 课程不愿关注等问题较为突出。

二、“三课堂联动”的机电一体化“课程思政”协同育

\section{人模式}

由于机电一体化专业采用 “订单班”培养模式, 学生 普遍具有强烈的专业认同感和优越感, 理性认识强, 专业 学习兴趣浓厚。其专业课程中本身就蕴含着爱岗敬业、服 务意识、节能环保、爱国情怀等丰富的隐性思政教育内容。 这为开展协同育人提供有力条件。在专业师生的共同努 力下, 逐步探索“三课堂联动”的机电一体化 “课程思政”协 同育人模式, 实现学生在专业学习的同时, 提高道德素养 和思想认识的职业素养培育目标。

\section{1、健全第一课堂“课程思政”运行机制}

第一, 在人才培养方案制定过程中, 明确提出思想政 治和职业素质要求; 第二, 在课程体系中设定思政课程, 开 设《轨道交通车站国家行业政策法规》、《城市轨道交通安 全管理》等专业选修课, 对学生进行思政和岗位素质教育; 第三, 在机电一体化专业课程标准思政说课的过程中, 对 教师在专业课程教学中思政工作的融人内容提出具体建 议和明确要求; 第四, 在专业教学过程中, 将培育与践行社 会主义核心价值观融人日常教学活动, 将“诚信”、“敬业” 等核心价值观念与“坚韧、善为、创新、求精”的宁波轨道交 通企业文化、“克难攻坚、团队协作”的员工岗位职责相结 合, 引导学生验证和运用所学知识与技能的应用素养, 培 养学生勇于担当、独立思考的职业素养; 第五, 深人拓展综 合素养课育人资源, 利用学校现有的《职业素养与职业道 德》《形式与政策》等综合素养课程资源, 将爱岗、敬业、责 任、担当等职业素养讲座课程与专业教学相结合, 实现专业 教育与思政教育的同向同行,形成齐抓共管的合力局面。

\section{2、加强第二课堂“棵程思政”协作机制}

一是加强专业技能型社团建设。以机电一体化专业 学生为基础, 组建专业技能型社团 “ $\mathrm{E}$ 港轨交志愿服务 社”。与宁波轨道交通集团有限公司运营分公司校企合作, 
秉承“奉献、友爱、互助、进步”的志愿精神, 以“坚韧、善为、 创新、求精”的企业文化和 “文明自信城院人”的校园文化 为服务指导, 以宁波轨交 $1 、 2$ 号线各站点为服务平台, 以 “文明出行、整洁有序”为服务目标, 建成“双主体、四接轨、 全过程” 的服务管理模式。“双主体”是指在志愿服务管理 上以宁波市轨道交通集团有限公司运营分公司团委、宁波 城市职业技术学院信息学院团总支为两个主体, 对志愿服 务队伍实行双重指导、双重管理和双重考核; “四接轨”是 指志愿服务内容上, 以“志愿服务培训要与岗位任职要求 相接轨、志愿服务内容要与工作任务相接轨、志愿者素质 培养与轨交企业文化、城院职业素养工作相接轨; “全过 程” 是指根据志愿服务开展情况, 通过现场巡视、岗前培 训、不定期反馈等方式, 宁波市轨道交通集团有限公司运 营分公司团委全程参与到志愿服务管理、志愿者服务内 容、志愿者考核等各个方面。积极开展与专业知识、专业 技能相结合的实践服务活动。

二是深化二课活动人文内涵。坚持核心价值观为引 导, 利用“三五学雷锋日”、“五四青年节”、“七一建党节”、 “二二 ‘运动”等重大节点, 通过 “重温人团誓词? 牢记责 任使命”五四主题活动、“当暑期社会实践遇上党的生日” 主题活动、“二二・而”红色海报、党团知识有奖竞答等系列 活动, 不断弘扬和传承优秀传统文化、红色革命文化、社会 主义先进文化, 歌颂身边人, 传递正能量, 丰富学生的人文 底蕴, 组织团员青年学党史、读党章、展望美丽宁波新发 展, 实现对文化的理性自觉与自信,引导团员青年投身“中 国梦”,坚定团员青年永远跟党走的信心。

\section{3、建立第三课堂“课程思政”联动机制}

首先, 充分利用校企合作平台, 邀请企业BOSS、行业 专家、优秀校友从用人单位、行业需求和社会现状等角度 剖析文化素养的重要性, 提出具体的人才特质需求, 为学 生全面发展指明方向; 其次, 始终坚持问题导向, 从学生学 习和生活中发现的问题出发, 鼓励和倡导学生上台, 通过 原生态的讲述或多形式的演绎, 引发思考, 进行互动, 实现 自我感悟, 坚持“学生互为老师”, 增强学生学习的积极性 和主动性, 提高教育的有效性; 第三, 秉承实践出真知的理 念, 组织学生参加 “六个一”专业认知(实践)活动, 即组织学 生在专业教师的指导下完成“拟定一个目标岗位、设计一 份个人简历、参加一次招聘会、走访一家目标企业、采访一 位在职员工、手写一份心得体会” 等六个规定动作, 引导学 生不断接触企业, 体验目标岗位职责。

\section{三、机电一体化“课程思政”协同育人的成效}

多年以来, 在宁波城市职业技术学院党政领导的支 持下, 在机电一体化专业全体师生的共同努力下, 机电一 体化“课程思政”协同育人在培育专业人才, 提升学生综合 素养过程中发挥了重要作用,成效显著。

第一,思想政治教育与专业学习的隔阂被打破,思想 政治理论课独自承担大学生思政教育的局面得到改善, 专业课程中的思政元素被充分挖掘, 专业课程有力的发
挥思政教育作用,提高了大学生思想政治教育的有效性。

第二,传统思想政治理论课强调理论, 学生普遍反映 其内容枯燥乏味。通过 “课程思政”教学改革之后, 与专业 教学相互融合、相互渗透, 既让思想政治理论课生动鲜活 起来, 又让专业课充满人情味, 激发了学生的学习热情, 提 高了学生对思政教育和专业知识的接受度。

第三, 通过 “课程思政”的实践, 学生既学到了知识和 掌握专业技能, 又在不知不觉中, 熟悉了本专业在实际工 作岗位中的职业素养要求, 诸如职业道德、职业操守、职业 纪律等职业素养在潜移默化中就自觉形成, 有效衔接了专 业发展与思政教育、企业要求与思政教育, 提升了学生对 专业岗位的适应能力。

第四, 在“课程思政”的实践过程中, 通过校企合作平 台开展各类第二课堂学生活动, 学生在不断接触企业、了 解企业的同时, 用人单位也对这些未来员工的个人状况有 了实时动态的了解和掌握, 便于企业依据实际需求, 对学 校的人才培养方式适时提出修改意见, 提高企业用人的针 对性培养。

第五,随着“课程思政”教学改革的逐步深人, 对专业 教师提出了更高的要求。教学过程中不断涌现出新的机 遇与挑战, 倒逼专业教师不断提高自身的专业素养和实践 教学能力, 有利于 “双师型”教师的培养。

\section{五、结束语}

在机电一体化 “课程思政” 协同育人取得成效的同 时, 依然面临着一些挑战: 例如, 课程思政在《人才培养方 案》中所处高度不够、部分专业教师认识不到位、学生活动 内涵建设有待加强、校企互动缺乏常态化机制等。习总书 记在全国教育大会上指出: 教育必须把培养社会主义建设 者和接班人作为根本任务。对于习总书记对高校加强思 想政治教育工作中提出的新理念和新要求, 高职院校应借 鉴此有益经验, 针对不同专业、不同学生的不同特点, 不断 探索“课程思政”新方式, 充分发挥高校教书育人的主阵地 作用, 致力于培养德智体美劳全面发展的社会主义建设者 和接班人。

\section{[参考文献]}

[1]习近平.把思想政治工作贯穿教育教学全过程 $[N]$. 新华网,2016-12-08.

[2]董少校.从“思政课程”到“课程思政”[N].中国教育 报,2016-12-02.

[3] 董洪亮、赵佪娜等. 习近平总书记在全国教育大会 上的重要讲话引起热烈反响——全力推动新时代教育工 作迈上新台阶[Z].人民日报,2018-09-12.

作者简介: 彭清 (1988.08-), 男, 江苏常州人, 硕士, 研究实 习员,研究方向: 大学生思想政治教育。

基金项目: 本文系宁波市高等学校思想政治教育研究会 2018 年研究课题“基于协同育人的高职“课程思政”工作 模式研究”(编号:SGXSZ18028)。 